Павловська С.В., кандидат історичних наук, провідний науковий співробітник науководослідної лабораторії НУО Украӥни імені Івана Черняховського (м. Київ)

\title{
ДІЯЛЬНІСТЬ РАДЯНСЬКИХ ВІЙСЬКОВИХ ІДЕОЛОГІЧНИХ СТРУКТУР СЕРЕД НАСЕЛЕННЯ ЗАХІДНОЇ УКРАЇНИ, БУКОВИНИ ТА БЕССАРАБІї У 1939-1940 pp.
}

У статті розглядаються аспекти політичної ідеології, пов'язані із насильнищьким насадженням радянських сочіально-політичних кліше населенню Західної України, Бессарабї, Північної Буковини на початку Другої світової війни. Авторкою з'ясовано яким чином ідеологічні структури Червоної Армії працювали з населенням країн Східної Європи з метою легітимізації приєднання цих територій до СРСР. Ці події стали визначними для формування політичного європейського конструкту на декілька десятиріч уперед.

Ключові слова: Друга світова війна, краӥни Східної Свропи, Червона армія, пакт Молотова-Ріббентропа, пропагандистська діяльність, ідеологічні органи РСЧА.

Сучасні геополітичні процеси у Східній Європі певною мірою відображають той політичний ландшафт, що почав формуватися ще напередодні Другої світової війни. Причини багатьох сучасних міжнаціональних конфліктів та політичних перетворень варто шукати саме у міжнародній діяльності останніх мирних років.

Мета статті - розглянути діяльність ідеологічних органів Червоної армії, що реалізовувала зовнішньополітичний курс радянського уряду i здійснювала заходи інформаційно-психологічного впливу на населення приєднаних територій з метою формування радянського світогляду. 
Операція РСЧА на території Західної України у вересні 1939 року потребувала легітимізації ii дій. Нагальним завданням було встановлення радянської влади. Радянське воєнно-політичне керівництво розуміло необхідність проведення потужної ідеологічної роботи серед населення на приєднаних територіях. Виконання цього завдання було покладено на військові ідеологічні органи.

Підготовка до акції “визволення” Західної України розпочалася у день підписання пакту Молотова-Ріббентропа. 23 серпня 1939 року Політичне бюро Центрального комітету Всеросійської комуністичної партії прийняло постанову “Про відбір 4000 комуністів для політроботи в РСЧА”. Постанова дозволяла Політуправлінню РСЧА призивати в армію політпрацівників запасу. Відбір кадрів здійснювався на найвищому рівні - на рівні політуправлінь, обласних, крайових та центральних комітетів партій республік [9, с. 146-148]. У жовтні 1939 року Військова рада Українського фронту утворила структуру “Комітет з організації та проведення виборів до Українських Народних Зборів” [2, с. 200].

Почалася активна робота серед населення Західної України щодо пропаганди комуністичної ідеології. Радянські ідеологи проаналізували соціальні та політичні аспекти існування українського населення на території Польщі. Було з'ясовано, що населення західноукраїнських земель зазнавало економічних, політичних та культурних утисків. На початку війни почалися відкриті репресії 3 боку польської влади. Радянська пропаганда реалізовувалася на сприятливому підгрунті народного невдоволення.

В архіві виявлено німецький документ - звіт німецького офіцера, який займався політичною пропагандою. Він звітував про зміст бесіди із польським священиком, який, за його словами, повідомив наступне: "У польський період, особливо під час уряду маршала Пілсудського, меншість раділа визволенню, яке наближалося. У цей період створювалися українські об’єднання, які без перешкод могли опікуватися за свій народ. Як результат, упродовж року виросло почуття власної гідності та бажання створити власну 
національну українську державу. Після смерті Пілсудського до початку війни польські кола дедалі частіше втручалися у справи українців” [15].

Визначення юридичного статусу західноукраїнських земель, відторгнутих від Польщі, мало відбутися на Народних Зборах уже в жовтні 1939 року. Для підготовки та проведення виборів армійські політоргани РСЧА виділили 7200 агітаторів і голів комісій різного рівня. Саме вони здійснювали тотальний контроль над усією передвиборчою кампанією [7, c. 70].

Під час вторгнення РСЧА до Польщі з боку армійських ідеологічних структур було розпочато широкомасштабну пропагандистську кампанію серед населення Західної України. Політвідділи Українського фронту розповсюдили більше 10 мільйонів листівок, що скидалися літаками над місцями проживання мешканців Західної України. Керівництво армійських політичних структур затвердило 11 тем для листівок, зміст яких був спрямований на дискредитацію польської влади: п'ять тем присвячувалися начебто втечі польського уряду за кордон, дві теми - фактам викрадення польським урядом золотого запасу, одна тема - розкішному життю представників польського уряду $[11$, с. 263]. У листівках розміщувалися заклики до дій проти поміщиків, заклики брати владу у свої руки та захоплювати панську землю [7, с. 70].

Комітет з організації та проведення виборів до Українських Народних Зборів розпочав широкомасштабну роз'яснювальну кампанію серед населення. Головним засобом завоювання уваги населення, яке щойно позбулося влади польських можновладців, були численні збори та мітинги селянства. За кожним населеним пунктом було закріплено уповноваженого, який щоразу зустрічався із селянами, інформуючи і пояснюючи переваги комуністичного устрою [7, с. 70].

3 метою поширення радянських ідеалів військові широко використовували можливості кінематографу. Для сільських мешканців це було новинкою. У розпорядженні політвідділу Українського фронту 
знаходилося 250 копій фільму “Щорс”, а загалом у кінотеці нараховувалось 80 назв популярних радянських фільмів [7, с. 70]. Не можна говорити про те, що соціальні та політичні нововведення були сприйняті усім населенням позитивно. Акції протесту мали місце, але вони не були поширеними i носили локальний характер.

Результатами проведеної ідеологічної роботи, про що свідчить радянська статистика, стали наступні показники: майже 93\% населення взяли участь у виборах, за пропонованих кандидатів проголосувало більше 90\% виборців. Скликані більшовиками Народні Збори 26-28 жовтня 1939 року ухвалили рішення про возз'єднання Західної України з УРСР [18, с. 94]. Вибори проводилися під цілковитим контролем НКВС і тиском радянської пропаганди. 1 листопада 1939 року відбулася п’ята позачергова сесія Верховної Ради СРСР, на якій було ухвалено рішення про прийняття цих земель до складу УРСР. А у грудні 1939 року Політичне бюро Центрального комітету комуністичної партії України затвердило склад партійно-радянської номенклатури новостворених областей у кількості 120 осіб. У подальшому було встановлено рознарядку по областях відносно відрядження до господарчих та партійних органів приєднаних земель комуністів та комсомольців із інших областей УРСР. Для забезпечення діяльності партійного та державного апарату зі східних областей України було відряджено понад п'ять тисяч комуністів та комсомольців. Крім того, до приєднаних земель було направлено 86 тисяч ідейно підготовлених фахівців різних кваліфікацій (вчителі, медики, агрономи тощо) зі Східної України, які були носіями комуністичної ідеології, радянського способу життя та мислення [7, с. 204-205].

Ідеологічна робота із населенням Західної України продовжувалася i після входження до складу СРСР. Одним із способів пропаганди радянського життя серед жителів Західної України стала практика організації показових екскурсій до Східної України, на проведення яких держава цілеспрямовано виділяла кошти. Так, у листопаді-грудні 1939 року Радою Народних 
комісарів УРСР спеціальною постановою було виділено з резервного фонду обласним виконавчим комітетам додаткові кошти у значних сумах $[18$, c. 220]. У великих українських містах екскурсанти відвідували заклади культури, знайомилися 3 умовами проживання та трудової діяльності громадян радянської України. Потім, повернувшись додому, вони мали розповідати на зборах і мітингах про свої враження. Такі заходи значно посилювали ефективність проведення заходів ідеологічного спрямування серед населення.

Однак воєнно-політичне керівництво СРСР займалося не лише створенням партійно-господарчого активу на щойно приєднаних територіях. Відповідна увага приділялася і заснуванню репресивної системи. 6 листопада 1939 року були підписані накази НКВС СРСР про організацію НКВС Західної України, а також територіальну та залізничну міліцію [1]. Одразу почалися репресивні дії, що стали основним засобом ідеологічної чистки, до яких залучалися і військові. На думку дослідників, 40 категорій населення від поліцаїв до філателістів підлягали негайному арешту та депортації із території приєднаних земель [18, с. 97].

Негативні наслідки дала і колективізація, яку почали проводити після приєднання. Селяни намагалися чинити опір новим формам господарювання, нав'язаним радянською владою. Одним із способів зниження активності селян було розповсюдження пияцтва, що фактично прищеплювалося місцевому населенню за рахунок доступності великої кількості алкогольних напоїв і використовувалося також як передумова ідеологічного впливу [7].

Натомість радянська влада здійснювала за короткий період заходи щодо облаштування лікувальних, освітніх, культурних закладів. Значна увага приділялася заснуванню засобів масової інформації із відповідною ідеологічною спрямованістю. Водночас відбувалася люстрація літератури у місцевих бібліотеках та школах. Припиняли існування культурні центри, які підкреслювали національну ідентичність окупованих РСЧА українських земель. Репресії, що проводились каральними органами проти місцевого 
населення, збурювали українське суспільство i поступово призвели до активізації націоналістичного підпілля.

Зовнішня політика СРСР по відношенню до Румунії відрізнялися від дій щодо приєднання польських територій лише формально. Свої претензії на Бессарабію, а згодом і на Північну Буковину Радянський Союз обгрунтовував належністю їх до українських етнічних територій та наявністю в них значної частки етнічних українців. Румунія, за порадою німецького фюрера, задля уникнення повномасштабного військового конфлікту була вимушена погодитися залишити ці території.

Як і під час подій у Польщі, радянська пропаганда широко використовувала серед місцевих мешканців особу С. Тимошенка, на той час уже народного комісара оборони СРСР. Але в цьому випадку наголос робився не на прізвищі, а на місці народження та соціальному походженні. М. Хрущов перед натовпом на одному з мітингів у Чернівцях сказав про С. Тимошенка як про “сина бессарабського селянина, який став у Країні Рад наркомом - взірцем тих потенційних можливостей, які відкриваються перед новими громадянами СРСР” [3, с. 362].

Місцеве населення, більшість етнічного складу якого становили національні меншини Румунії, у цілому радо зустрічало прихід Червоної армії, висловлювали подив і захоплення від вигляду потужної радянської військової техніки та “демократичного поводження радянських командирів”, 3 якими можна було вільно спілкуватися. Червоноармійці виявляли свою прихильність до населення: возили бессарабів і буковинців на броні танків, “давали постріляти” з особистої зброї тощо, що несхвально сприймалося військовим командуванням [6].

Румунський похід РСЧА проходив під пропагандистським гаслом захисту чисельної української громади. Йшлося вже не про приєднання земель та населення до УРСР, а про повернення території “матері-вітчизні СРСР”. До числа “єдинокровних братів” разом із українцями та росіянами, зараховано також молдован та представників інших народів. Офіційними 
мовами були російська та румунська, а не українська. Газети в більшості населених пунктів, зокрема, в Кишиневі, Аккермані, Бєльцях, Бендерах, Ізмаїлі, Кагулі, Сороках, Хотині планувалося спочатку видавати румунською мовою (в молдовському Кишиневі ще й російською), а українською - тільки у місті Чернівці, заселеному переважно єврейським населенням. Так готувалося підгрунтя для створення у складі СРСР ще однієї союзної республіки - молдавської [3, с. 364].

Окрім офіційних повідомлень про схвальне ставлення місцевого населення анексованих територій до УРСР, є достатньо документальних свідчень іншого характеру. Про зловживання радянської влади у боротьбі 3 капіталістичним засобом життя на щойно приєднаних територіях йдеться у доповідній прокурора Яченіна на ім'я М. Хрущова, датованій 10 січням 1940 року. Відповідно до постанови Ради народних комісарів від 9 грудня 1939 року про націоналізацію промислових та торгових підприємств, вказувалося на необхідність націоналізації великих будівель, що належали буржуазії, фабрикантам та куркулям.

У Львові це питання вирішувалося по-іншому. Всього у Львові нараховувалося 15000 будинків. Спочатку склали список на 13000 будинків, що підлягали націоналізації. Потім цей перелік зменшили до 6400 будинків та внесли до цього списку домівки багатьох трудящих, фахівців, інженерів, лікарів. Термін проведення націоналізації було встановлено у $3-4$ дні. Націоналізацію почали без будь-якої підготовки. Було утворено близько 300 бригад, яким роздали списки будинків, що підлягали націоналізації [16].

Всього за декілька діб було націоналізовано 3800 будинків. Націоналізація у багатьох випадках супроводжувалася не лише виселенням власників, а й тих, хто знімав житло, підселенням по декілька осіб в одну кімнату. Крім того, націоналізація супроводжувалася конфіскацією усього майна домовласника, опечатуванням речей, меблів, одягу, навіть продуктів харчування. Мали місце випадки, коли “...конфісковували ложки, виделки, знімали годинники з рук, браслети, каблучки. Описи цього майна складалися 
без відома власника, або не підписувалися, що сприяло створенню підгрунтя для розбазарювання".

У доповідній радянський прокурор наводить наступний приклад: “27.ХІІ.1939 р. Комісія червоноармійської районної ради націоналізувала будинок № 24 по вулиці Листопада. Будинок має 10 кімнат, однак 2/3 будівлі належать службовцю Д.М. Фогелю. Уповноважений районної ради Карпенко будинок націоналізував. При цьому він забрав: срібні ложки, ножі, браслет та 900 карбованців заробітної платні, яку отримав Фогель. Усі меблі, одяг та білизну було знесено до однієї кімнати, яку Карпенко опечатав. Характерно, що донька Фогеля працює вчителькою музичної школи. Але це не завадило реквізувати піаніно й опечатати його в кімнаті. Паливом, яке було у підвалі, комісія теж заборонила користуватися" [16].

Незважаючи на зловживання та насильницький характер радянізації, усі заходи по роботі з населенням Західної України носили організований характер. армійські ідеологічні структури реалізовували зовнішньополітичний курс СРСР та використовували усі можливі ресурси для здійснення інформаційно-психологічного впливу на місцеве населення приєднаних територій. Для здійснення широкомасштабних заходів інформаційно-психологічного впливу вони мали відповідне матеріальнотехнічне та фінансове забезпечення. Керівництво Головного управління РСЧА особливо ретельно підходило до відбору і підготовки фахівцівідеологів для роботи з місцевим населенням. Проведена пропагандистська кампанія щодо легітимізації незаконної територіальної анексії сприяла формуванню нової політичної ідеології. Населення Західної України неоднозначно сприймало зміни у життєвому укладі та необхідність дотримуватися нових політичних стандартів. Усе це створювало підвалини для формування майбутніх протестних рухів та конструювання сучасного європейського ландшафту. 


\section{Список використаних джерел і літератури}

1. Гаврилів І.О. Більшовицький терор на Західноукраїнських землях у1939-1941 рр.: [Електрон. ресурс]. - Режим доступу : http://vlp.com.ua/files/24_6.pdf

2. Головко М.Л. Суспільно-політичні організації та рухи України в період Другої світової війни. 1939-1945 рр. : монографія. - К. : Олан, 2004. $704 \mathrm{c.}$

3. Гриневич В.А. Червона армія у війнах і військових конфліктах 19391940 рр.: військово-політичні, ідеологічні та соціально-психологічні аспекти // Проблеми історії України. Факти, судження, пошуки (міжвідомчий збірник наукових праць). - К. : Інститут історії України НАН України. - Т. 2. -Вип. 19: [Електрон. ресурс]. - Режим доступу : http://history.org.ua/JournALL/pro/10/20.pdf

4. Крисько В.Г. Секреты психологической войны (цели, задачи, методы, формы, опыт) [Под общ. ред. Тараса]. - Мн., 1999.

5. Лисенко О.С., Пилявець Р.І. Пакт Молотова-Ріббентропа 1939. Енциклопедія історії України: Т. 8. Па - Прик / Редкол.: В. А. Смолій (голова) та ін. НАН України. Інститут історії України. - К. : Вид-во “Наукова думка", 2011. - 520 c.: [Електрон. ресурс]. - Режим доступу : http://www.history.org.ua/?termin=Pakt_M_R (останній перегляд: 14.07.2019).

6. “Наша зелена Буковина одягнула святковий одяг” Голос України 2010.08.07: [Електрон. ресурс]. - Режим доступу : http://lib.rada.gov.ua/static/about/vistupi_text/Martinyuk/golos_10_08_07.html

7. Політична історія України XX століття. У шести томах. Т.4-й: Україна у Другій світовій війні. (1939-1945) / Керівник тому В.І. Кучер. - К., 2004. - 584 c.

8. Приказ Народного Комиссара Обороны Союза ССР 7 ноября 1939 года: [Електрон. ресурс]. https://ru.wikisource.org/wiki/№_199 
9. Про військову перепідготовку, переатестування працівників партійних комітетів і про порядок їх мобілізації в РСЧА. Постанови Політбюро ЦК ВКП(б) 13 березня 1940 р // Коммунистическая Партия Советского Союза в резолюциях и решениях съездов. Конференций и пленумов ЦК. - Т.7. - М., 1985. - 574 с.: [Електрон. ресурс]. - Режим доступу : http://elib.shpl.ru/ru/nodes/8617-t-7-1938-1945-1985-574s\#mode/inspect/page/566/zoom/5

10. Скан копія документа: [Електрон. ресурс]. - Режим доступу : http://historyfoundation.ru/2019/05/31/pakt/?fbclid=IwAR3pGl4buNRaTvs0bguz5 KtzOIOnGIT4F_MN7_GfsVAukN5hHRqfta0uKRk

11. Стенограмма заседаний Международного Военного Трибунала от 28 марта - 2 апреля 1946: [Електрон. ресурс]. - Режим доступу : http://militera.lib.ru/docs/da/np_doprosy/ribbentrop-d.html

12. Судоплатов П.А. Спецоперации. Лубянка и Кремль 1930-1950 годы. - М. : ОЛМА-ПРЕСС, 1997: [Електрон. ресурс]. - Режим доступу : http://militera.lib.ru/memo/0/one/russian/sudoplatov_pa.rar

13. Хрестоматия по истории международных отношений. Книга 4. Новейшее время [Составитель Д.В. Кузнєцов]. - Благовещенськ, 2013. 179 с.: [Електрон. ресурс]. - Режим доступу: http://stomfaq.ru/kniga-4novejshee-vremya-sostavitele-d-v-kuznecov-blagoveshens/index39.html\#pages

14. Центральний Державний архів громадських організацій України (далі -ЦДАГОУ).

15. ЦДАГОУ, ф. 1, оп. 23, сп. 974, арк. 64.

16. ЦДАГОУ, ф. 1, оп. 23, д. 47, арк. 8.

17. ЦДАГОУ, ф. 1, оп. 23, д. 47, арк. 9.

18. Шайкан В. Ідеологічна боротьба в Україні періоду Другої світової війни 1939-1945 рр. : монографія. - Кривий Ріг : Діоніс, 2010.

19. Шайкан В. Більшовики і Західна Україна на початковому етапі Другої світової війни / В. Шайкан // Сторінки воєнної історії України. - 2010. - № 13. - С. 1-3. 
Pavlovska S.V., Candidate of Historical Sciences, Leading Researcher of Research Laboratory of Ivan Cherniakhovskyi National Defense University of Ukraine (Kyiv)

\section{WORK OF THE SOVIET MILITARY IDEOLOGICAL STRUCTURES AMONG THE POPULATION OF THE WESTERN UKRAINE, BUKOVYNA AND BESSARABIA IN 1939-1940}

In this paper, the aspects of political ideology that are associated with the forced planting Introduction of Soviet socio-political cliches into the population of the occupied territories by the Red Army Western Ukraine, Bessarabia, Northern Bukovyna are considered. Geographic signs for the population of annexed territories remained unchanged, but state and political borders changed. How the ideological structures of the Red Army worked with the population of Eastern European countries in order to legitimize the accession of these territories to the USSR. There were decisive measures for the formation of a political European structure for several decades ahead.

Keywords: Second World War, Red Army, Molotov-Ribbentrop Pact, propaganda activities, ideological structures of the Red Army, annexation. 